\title{
Leveraging Genomic Associations in Precision Digital Care for Weight Loss: Cohort Study
}

\section{Supplementary Material}

This is a Supplementary Appendix to a full manuscript published in the J Med Internet Res.

For full copyright and citation information see http://dx.doi.org/10.2196/25401

Table S1: Genomic variables significant to one or more of the 3 models utilizing genomic data

\begin{tabular}{|c|c|c|c|c|c|c|c|c|c|c|c|c|}
\hline & \multicolumn{4}{|c|}{ Participants: $\mathrm{n}=392$} & \multicolumn{4}{|c|}{ Male: $n=77(19.6 \%)$} & \multicolumn{4}{|c|}{ Female: $n=315(80.4 \%)$} \\
\hline SNP & $\begin{array}{c}0 \text { risk } \\
\% \\
\end{array}$ & $\begin{array}{c}1 \text { risk } \\
\% \\
\end{array}$ & $\begin{array}{c}2 \text { risk } \\
\% \\
\end{array}$ & $\begin{array}{c}\text { no } \\
\text { value } \%\end{array}$ & $\begin{array}{c}0 \text { risk } \\
\%\end{array}$ & $\begin{array}{c}1 \text { risk } \\
\% \\
\end{array}$ & $\begin{array}{c}2 \text { risk } \\
\% \\
\end{array}$ & $\begin{array}{c}\text { no } \\
\text { value\% }\end{array}$ & $\begin{array}{c}0 \text { risk } \\
\% \\
\end{array}$ & $\begin{array}{c}1 \text { risk } \\
\%\end{array}$ & $\begin{array}{c}2 \text { risk } \\
\%\end{array}$ & $\begin{array}{c}\text { no } \\
\text { value\% }\end{array}$ \\
\hline rs10246939 & 25.26 & 47.45 & 27.30 & 0.00 & 22.08 & 51.95 & 25.97 & 0.00 & 26.03 & 46.35 & 27.62 & 0.00 \\
\hline rs1042 & 33.42 & 50.51 & 4.80 & & 37.66 & 48.05 & 99 & 1.30 & 32. & 1.11 & & 1.27 \\
\hline rs107 & 15.82 & 41.33 & 2.86 & 0.00 & 14.29 & 41.56 & 44.16 & 0.00 & 16.1 & 1.27 & 54 & 0.0 \\
\hline rs1501299 & 7.14 & 45.41 & 47.45 & 0.00 & 5.19 & 48.05 & 46.75 & 0.00 & 7.62 & 4.76 & 47.62 & 0.00 \\
\hline rs173000539 & 1.02 & 13.78 & 85.20 & 0.00 & 0.00 & 15.58 & 84.42 & 0.00 & 1.27 & 13.33 & 85.40 & 0.00 \\
\hline rs1799931 & 88.52 & 11.22 & 0.26 & 0.00 & 93.51 & 6.49 & 0.00 & 0.00 & 87.30 & 2.38 & 0.32 & 0.00 \\
\hline rs201 & 62.24 & 32.40 & 5.10 & 0.26 & 57.14 & 38.96 & 3.90 & 0.00 & 63.4 & 0.79 & 5.40 & 0.32 \\
\hline rs2112347 & 17.09 & 43.11 & 39.54 & 0.26 & 23.38 & 42.86 & 32.47 & 1.30 & 15.56 & 43.17 & 41.27 & 0.00 \\
\hline rs2185570 & 75.51 & 22.96 & 0.51 & 1.02 & 75.32 & 22.08 & 1.30 & 1.30 & 75.56 & 23.17 & 0.32 & 0.95 \\
\hline rs236918 & 4.34 & 19.39 & 76.02 & 26 & 2.60 & 18.18 & 79.22 & 0.00 & 4.76 & 19.68 & 75.24 & 0.32 \\
\hline rs4074995 & 60.71 & 30.36 & 8.93 & 0.00 & 55.84 & 31.17 & 12.99 & 0.00 & 61.90 & 30.16 & 7.94 & 0.00 \\
\hline rs7138803 & 45.92 & 45.41 & 8.67 & 0.00 & 41.56 & 54.55 & 3.90 & 0.00 & 46.98 & 43.17 & 9.84 & 0.00 \\
\hline rs7903146 & 54.08 & 35.20 & 10.71 & 0.00 & 57.14 & 37.66 & 5.19 & 0.00 & 53.33 & 34.60 & 12.06 & 0.00 \\
\hline rs9376026 & 30.36 & 45.41 & 24.23 & 0.00 & 27.27 & 50.65 & 22.08 & 0.00 & 31.11 & 44.13 & 24.76 & 0.00 \\
\hline
\end{tabular}

Table S1: In all, 197 genomic variables from Digbi Health's curated panels were examined in this study; those that were significant to one or more models are reported here. These SNPs are not sex-related variants, and no significant difference was detected between males and females (Welch's two-sample t-test with Benjamini-Hochberg correction for multiple hypothesis testing, results not shown). 
Table S2 Gender Distribution

\begin{tabular}{|c|c|c|}
\hline Gender & $\begin{array}{c}\text { Number of } \\
\text { participants }\end{array}$ & $\begin{array}{c}\text { Number of } \\
\text { participants (\%) }\end{array}$ \\
\hline Female & 315 & 80.2 \\
\hline Male & 77 & 19.6 \\
\hline Decline to state & 1 & 0.2 \\
\hline
\end{tabular}

Table S2: Distribution of Digbi Health study participants by gender

Table S3: Weight Change in Study Participants

\begin{tabular}{|c|c|c|}
\hline $\begin{array}{c}\text { Weight change } \\
\text { status }\end{array}$ & $\begin{array}{c}\text { Number of } \\
\text { participants }\end{array}$ & $\begin{array}{c}\text { Number of } \\
\text { participants (\%) }\end{array}$ \\
\hline Gained Weight & 42 & 10.7 \\
\hline $\begin{array}{c}\text { Negligible } \\
(<2 \text { lb) change }\end{array}$ & 68 & 17.3 \\
\hline Lost Weight & 283 & 72.0 \\
\hline
\end{tabular}

Table S3: Distribution of participants by weight change status on Day 120 in Digbi Health program

Table S4 - BMI Shift in Study Participants

\begin{tabular}{|c|c|c|}
\hline $\begin{array}{c}\text { Weight change } \\
\text { category }\end{array}$ & $\begin{array}{c}\text { Number of } \\
\text { participants }\end{array}$ & $\begin{array}{c}\text { Number of } \\
\text { participants (\%) }\end{array}$ \\
\hline $\begin{array}{c}\text { Shifted to higher } \\
\text { BMl class }\end{array}$ & 7 & 1.7 \\
\hline $\begin{array}{c}\text { No change } \\
\text { in BMl class }\end{array}$ & 288 & 73.3 \\
\hline $\begin{array}{c}\text { Shifted to lower } \\
\text { BMl class }\end{array}$ & 98 & 25.0 \\
\hline
\end{tabular}

Table S4: Distribution of participants by shift in BMI class by Day 120 in Digbi Health program 
Table S5: Obesity classes of participants, before and after treatment

\begin{tabular}{|c|c|c|}
\hline $\begin{array}{c}\text { BMI } \\
\text { class }\end{array}$ & $\begin{array}{c}\text { Number of participants in class } \\
\text { at program start }\end{array}$ & $\begin{array}{c}\text { Number of participants in } \\
\text { class post 120 days }\end{array}$ \\
\hline Normal & 5 & 16 \\
\hline Overweight & 87 & 108 \\
\hline Class I & 136 & 133 \\
\hline Class II & 91 & 81 \\
\hline Class III & 74 & 55 \\
\hline
\end{tabular}

Table S5: Obesity classes were categorized into Normal (BMI $<25)$, Overweight $(25<=\mathrm{BMI}<30)$, Class I $(30<=\mathrm{BMI}<35)$, Class II $(35<=\mathrm{BMI}<40)$, and Class III (BMI $>=40)$.

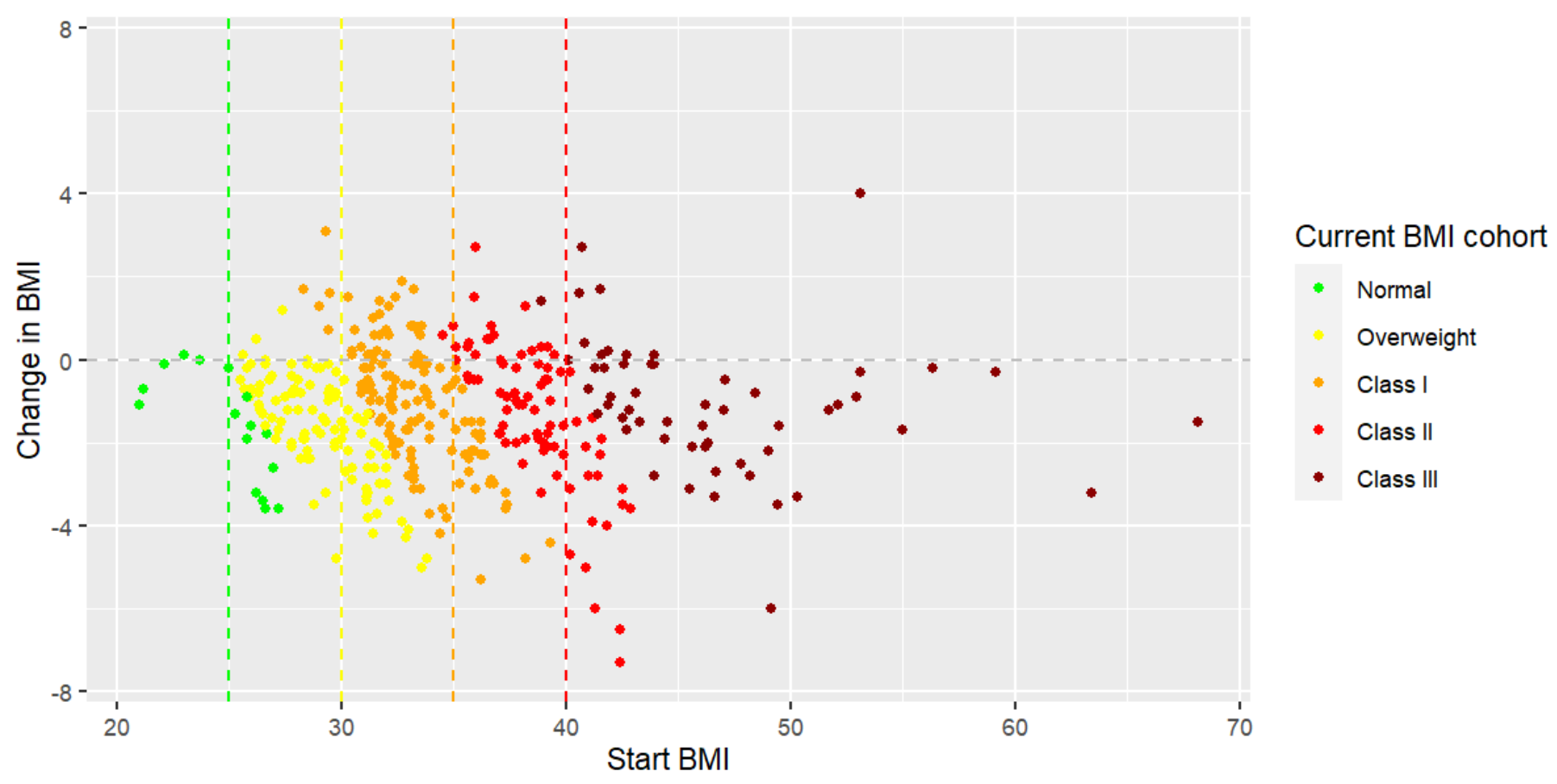

Figure S1: Change in BMI class vs Baseline BMI by Day 120 BMI Class. Post 120 days in the program, a positive shift of number of individuals across BMls classes was observed. The dispersion of obesity classes based on baseline weight and current weight in the cohort are displayed in Figure S1 and Tables S4 and S5. 


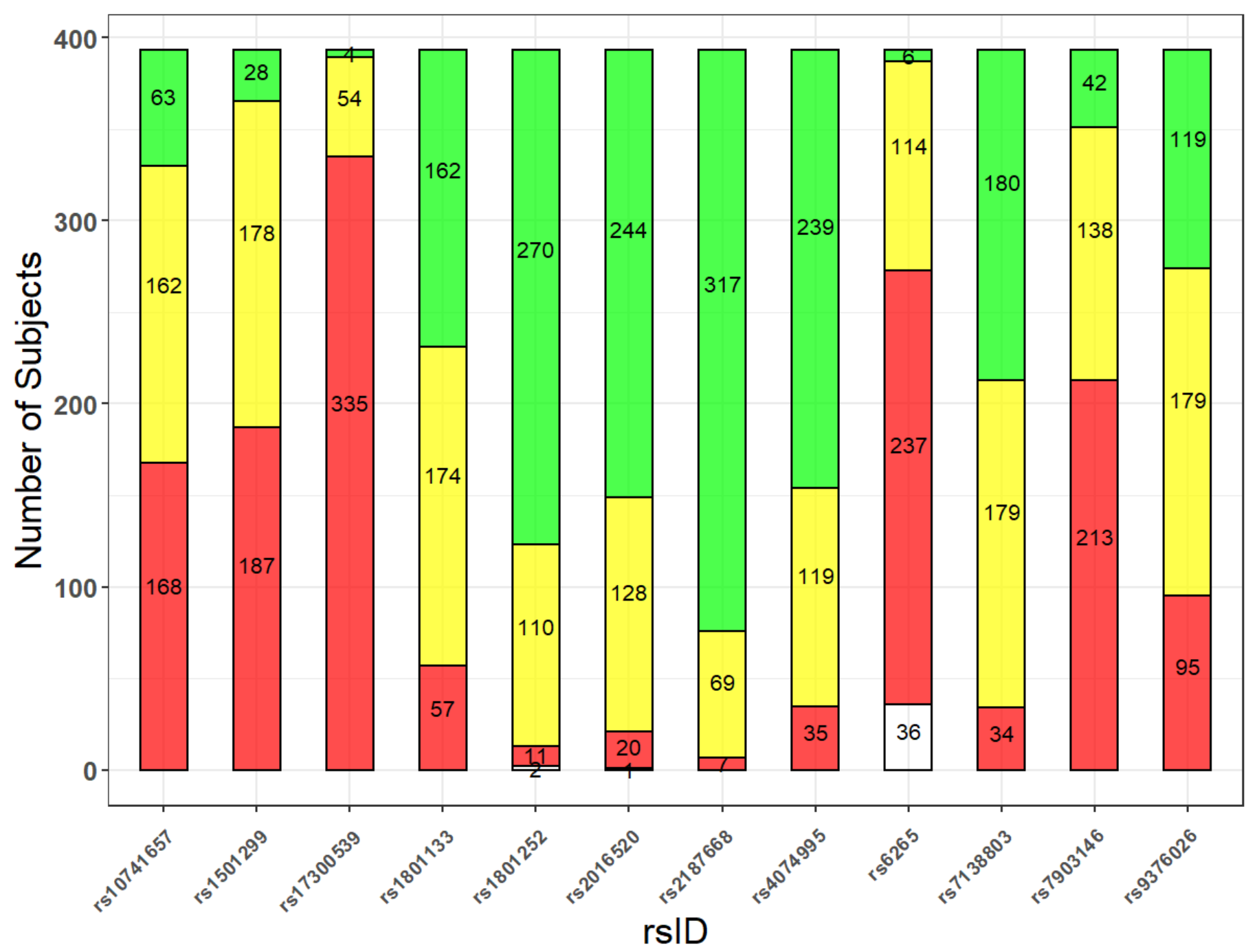

Number of Risk Alleles Present $\square 0 \square 1 \square 2 \square$ NA

\section{Figure S2: Distribution of Selected SNPs across Digbi Health Subjects}

Rs 10741657 has been linked to serum concentrations of Vitamin D, with carriers of the $G$ allele having lower levels of Vitamin D [117], rs1501299 is a variant of the ADIPOQ gene encoding adiponectin [118], rs1801133 is in the MTHFR gene which is involved in folate metabolism with A allele implicated in lower enzymatic activity [119], rs1801252 is in the ADRB1 gene whose encoded protein is the target of beta blocker drugs for reducing hypertension [120], rs2016520 is associated with baseline cholesterol levels [84], rs2187668 is related to autoimmune disease and is implicated in both lupus and celiac disease [121, 122], rs4074995 is associated with serum calcium levels [88], rs6265 has been associated with caffeine metabolism profiles [123], and rs7138803 is associated with measures of obesity [124]. 
A

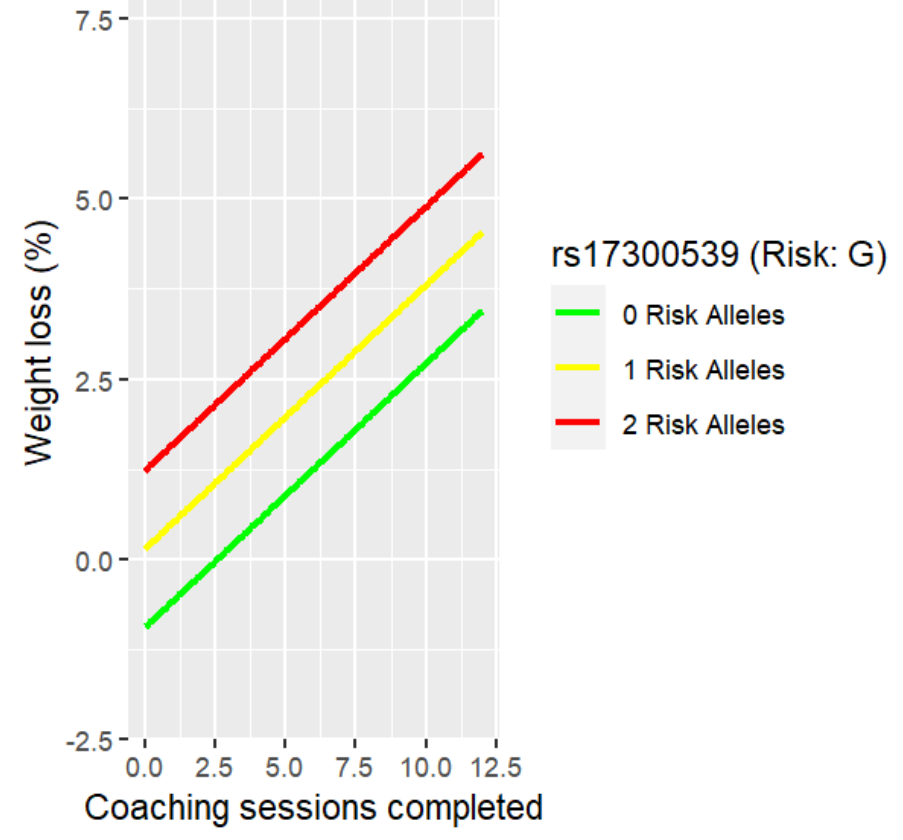

B

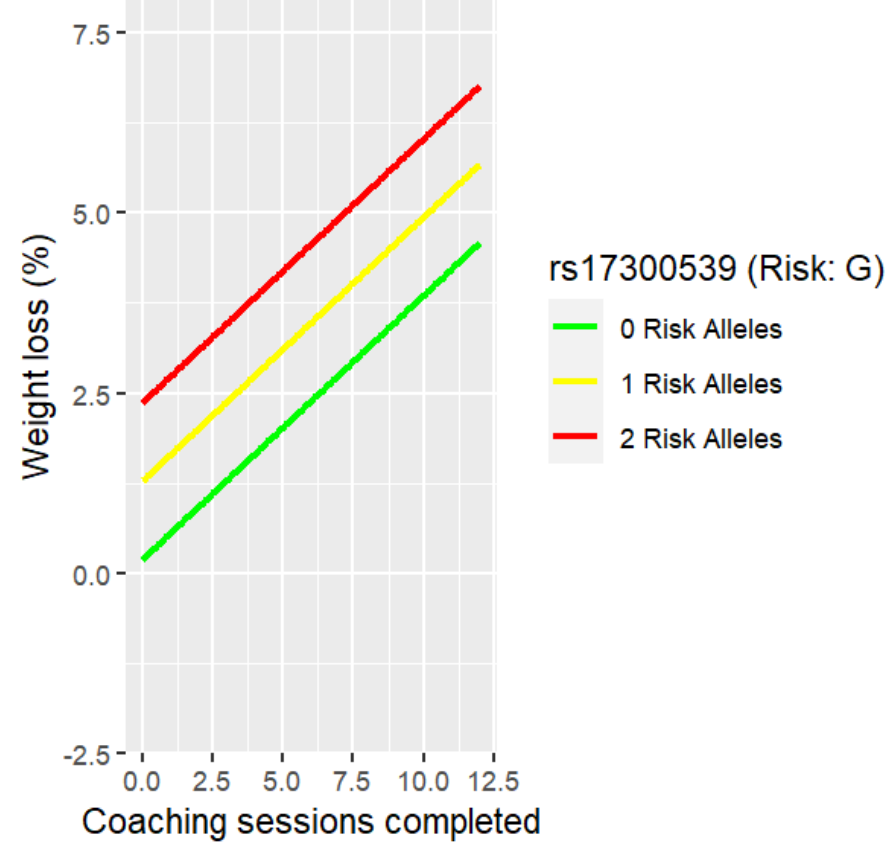

Figure S3: Weight loss (\%) vs Coaching by rs17300539 (mono unsaturated fats intake and weight gain tendency SNP) in females (A) compared with males (B).

$\mathbf{A}_{30-}$

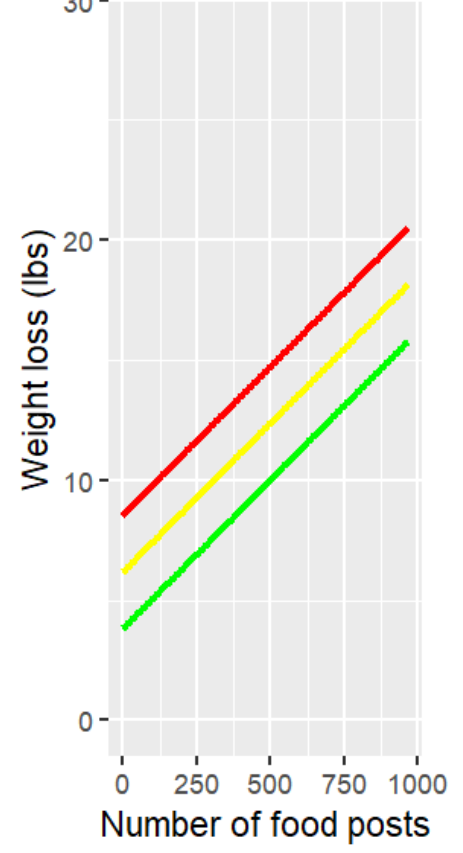

B

$B_{30-}$

rs2016520 (Risk Allele: C)

- 0 Risk Alleles

1 Risk Alleles

2 Risk Alleles

Figure S4: Weight loss (lb) vs number of food photos posted by rs2016520 (cholesterol SNP) in females (A) compared with males (B). 


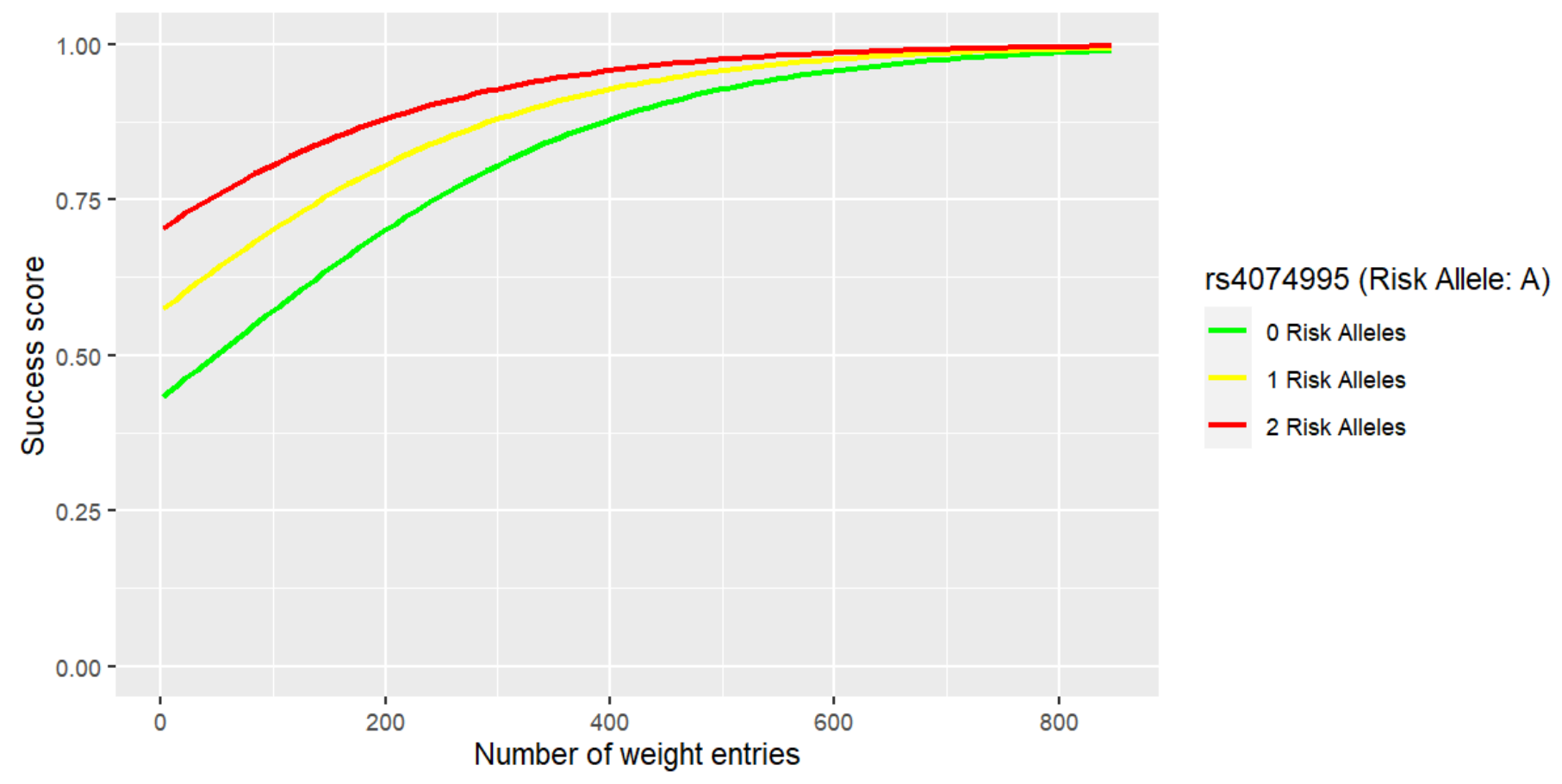

Figure S5: Weight loss success vs number of weight entries by rs4074995 (calcium-potassium SNP). The logistic regression success score is the likelihood of this model assigning the participant to the success class. Success score is depicted as a function of number of weight entries logged in the Digbi Health app (a behavioral engagement measure) by allele value of rs 4074995 . This SNP is varied over 0,1 , and 2 risk alleles. All other SNPs in the model were held constant at their most frequent value.
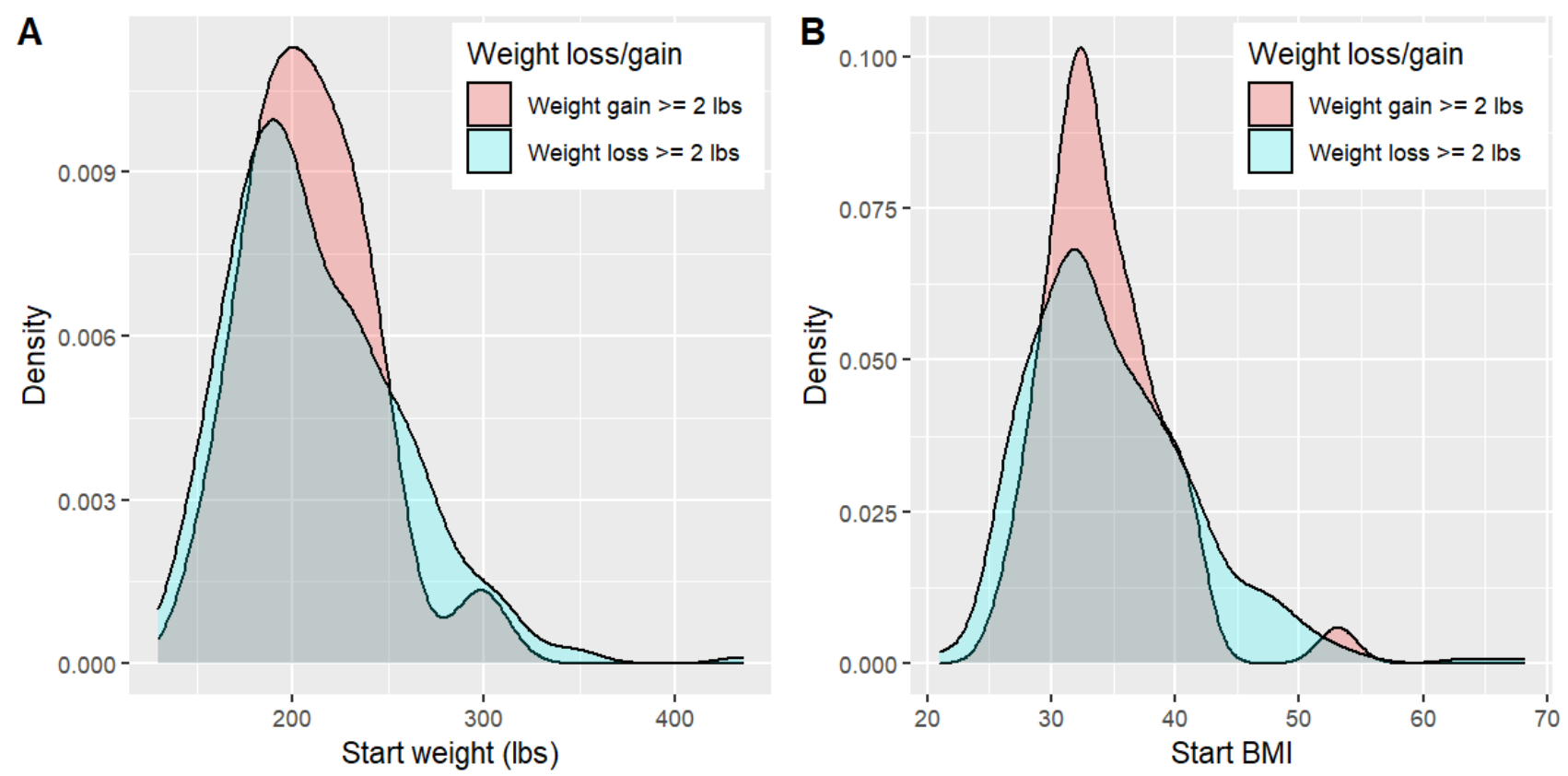

Figure S6: Baseline Weight Distributions are Similar for participants who gained versus lost weight. No statistical difference in means in A) start weight and B) start BMI, confirmed by Welch's two-sample ttest ( $P=.64$ and $P=.42$ respectively.) between subjects who lost (Blue) vs. gained (Red) weight. Less than 2 lbs gain or loss was considered negligible and excluded from this figure. 
Table S6

Linear Model Weight Loss in Pounds WITHOUT Genomic Information

\begin{tabular}{|l|l|l|}
\hline Variable & Estimate & $P$-value \\
\hline Male Gender & -4.691200 & $P<.001$ \\
\hline Starting BMI & 0.175610 & $P=.006$ \\
\hline $\begin{array}{l}\text { Number of Food Photos } \\
\text { Posted }\end{array}$ & 0.013287 & $P<.001$ \\
\hline $\begin{array}{l}\text { Number of Coaching } \\
\text { Sessions Completed }\end{array}$ & 0.765527 & $P<.001$ \\
\hline
\end{tabular}

\section{Table S7}

Linear Model Weight Loss in Pounds WITH Genomic Information

\begin{tabular}{|l|l|l|}
\hline Variable & Estimate & $P$-value \\
\hline Number of coaching sessions & 0.787908 & $P<.001$ \\
\hline Male gender & -4.663601 & $P<.001$ \\
\hline Number of food posts & 0.012398 & $P<.001$ \\
\hline rs2016520 & 2.362252 & $P<.001$ \\
\hline Start BMI & 0.199397 & $P=.001$ \\
\hline rs10741657 & -1.750832 & $P=.002$ \\
\hline rs4074995 & 1.617627 & $P=.01$ \\
\hline rs7138803 & -1.682353 & $P=.008$ \\
\hline rs9376026 & 1.715229 & $P=.002$ \\
\hline rs236918 & 1.908988 & $P=.01$ \\
\hline rs10246939 & -1.118222 & $P=.047$ \\
\hline rs1042713 & 1.437565 & $P=.02$ \\
\hline rs2112347 & 1.310121 & $P=.02$ \\
\hline rs2185570 & 1.859366 & $P=.04$ \\
\hline
\end{tabular}


Table S8

Linear Model Weight Loss \% WITHOUT Genomic Information

\begin{tabular}{|l|l|l|}
\hline Variable & Estimate & $P$-value \\
\hline Male gender & -1.258215 & $P=.01$ \\
\hline Number of food posts & 0.006337 & $P<.001$ \\
\hline Number of coaching sessions & 0.371819 & $P<.001$ \\
\hline
\end{tabular}

\section{Table S9}

Linear Model Weight Loss \% WITH Genomic Information

\begin{tabular}{|l|l|l|}
\hline Variable & Estimate & $P$-value \\
\hline Number of coaching sessions & 0.366315 & $P<.001$ \\
\hline Number of food posts & 0.005971 & $P<.001$ \\
\hline rs2016520 & 1.161539 & $P<.001$ \\
\hline rs9376026 & 0.947039 & $P<.001$ \\
\hline rs236918 & 1.232999 & $P<.001$ \\
\hline rs10741657 & -0.824197 & $P=.002$ \\
\hline rs4074995 & 0.817030 & $P=.006$ \\
\hline rs7138803 & -0.824408 & $P=.006$ \\
\hline rs1042713 & 0.834681 & $P=.004$ \\
\hline Male gender & -1.182711 & $P=.01$ \\
\hline rs2112347 & 0.767689 & $P=.005$ \\
\hline rs7903146 & 0.593860 & $P=.04$ \\
\hline rs17300539 & 1.088278 & $P=.04$ \\
\hline rs1501299 & -0.699880 & $P=.03$ \\
\hline
\end{tabular}


Table S10

Logistic Regression Model WITHOUT Genomic Information.

\begin{tabular}{|l|l|l|l|}
\hline Variable & Odds Ratio & $2.5 \%$ & $97.5 \%$ \\
\hline $\begin{array}{l}\text { Number of weight } \\
\text { entries logged }\end{array}$ & 1.006 & 1.002 & 1.009 \\
\hline $\begin{array}{l}\text { Number of coaching } \\
\text { sessions completed }\end{array}$ & 1.304 & 1.169 & 1.465 \\
\hline
\end{tabular}

\section{Table S11}

Logistic Regression Model WITH Genomic Information.

\begin{tabular}{|l|l|l|l|}
\hline Variable & Odds Ratio & $2.5 \%$ & $97.5 \%$ \\
\hline rs2016520 & 1.985 & 1.134 & 3.595 \\
\hline rs7138803 & 0.534 & 0.318 & 0.872 \\
\hline rs10741657 & 0.617 & 0.400 & 0.937 \\
\hline rs4074995 & 1.765 & 1.106 & 2.878 \\
\hline rs9376026 & 1.804 & 1.167 & 2.85 \\
\hline rs1799931 & 0.293 & 0.097 & 0.822 \\
\hline $\begin{array}{l}\text { Number of weight } \\
\text { entries logged }\end{array}$ & 1.006 & 1.002 & 1.009 \\
\hline $\begin{array}{l}\text { Number of coaching } \\
\text { sessions completed }\end{array}$ & 1.356 & 1.200 & 1.546 \\
\hline
\end{tabular}

